\title{
MARKET STRUCTURE AND COMPETITION PRICE IN ISLAMIC ECONOMICS
}

\author{
Dadang Mulyana \\ STAI Muhammadiyah Bandung, Indonesia \\ Email: damul02@staim-bandung.ac.id
}

\begin{abstract}
This article will discuss market structure and competition prices in islamic economics. Literature searching is the method used in writing this article. This article found that market in Islam is defined as a means of meeting between seller and buyer, where the buyer came to the market with a demand for goods membewa certain to meet with the seller that brings offers the same goods as well. And the outcome of the meeting will produce an agreement between the seller and the buyer of the price level and the number of items in the transaction. If an agreement between the seller and the buyer then there was a provision of an item in the transaction. The market structure has a notion that some form of management of the producer to the market based on their characteristics, for example, such as the type of product produced, the number of companies in an industry. Easy or not exit or enter the industry and the role of advertising in industry activity. Perfect competition is a market structure that is most ideal for systems market is considered to ensure their activities to produce goods or services is high. The conclusion of the article are: however, in practice it is not easy to realize a market that has a structure of perfect competition. pricing is one of the practices that are not allowed by the Islamic Shari'a. Government or who have economic power do not have the right and authority to determine the fixed price of a commodity, unless the government has provided for the trader's sufficient quantities to be sold using a price has been agreed. Tabi'at (fixed) This we can see from how the attitude of the prophet Muhammad pbuh on the issue. When visited by a companion to ask for fixing the price, the Prophet pbuh stated his rejection.
\end{abstract}

Keywords: Market; Perfect Competition; Imperfect Competition; Monopoly; Oligopoly

\section{A. INTRODUCTION}

The market is a place or process of interaction between demand (buyer) and supply (seller) of a particular good/service, so that it can finally determine the equilibrium price (market price) and the amount traded (Klein, 2010, p. 73). So, every process that brings together buyers and sellers will form a price agreed upon between the buyer and seller. Knowledge of market structure and efficiency is important for economic actors and is needed in planning and making business decisions both by companies individually and by economic policy makers (Beckert, 2009, p. 38).

Microeconomics is a branch of economics that studies the behavior of consumers and companies and determines market prices and the quantity of factors of inputs, goods, and services that are traded (Pate, 2012, p. 29). Microeconomics examines how various decisions and behaviors affect the supply and demand of goods and services, which determine prices, and how prices, in turn, determine the supply and demand for further goods and services. Individuals who make a combination of consumption or production optimally, together with other individuals in the market, will form a balance on a macro scale, (Arnold, 
2008, p. 14) assuming that all other things remain the same (ceteris paribus) (Tucker, 2008, p. 8).

Issues of Microeconomics will not be detached from the market because they are interrelated, one of the objectives of microeconomics is to analyze the market and its mechanisms that form prices relative to products and services, and the allocation of a limited number of people among many alternative users (Baumol \& Blinder, 2008, p. 309). Therefore, this article will try to examine Market Structure and Price Competition in the Problems of Microeconomics and link them to the development of Islamic Microeconomics.

\section{B. METHOD}

This article was written using the literature survey method. This method is used to utilize library resources in obtaining data, tracking existing resources to build an analysis and interpretation framework (Thomas, 1998, p. 73).

\section{RESULT AND DISCUSSION}

\section{Market Structure}

Market structure is a market condition that provides guidance on aspects that have an important influence on business behavior and market performance, including the number of sellers and buyers, barriers to market entry and exit, diversity of products, distribution systems and market share control (Tarakan, 2000, pp. 70-95).

There are several basic distinctions that influence decisions (behavior) between sellers and buyers in a market structure, namely as follows (Pracoyo \& Pracoyo, 2006, p. 188):

a. Number of companies in the market / industry.

b. Types of goods that are traded, including homogeneous or heterogeneous items.

c. Whether or not an easy new company enters the market.

d. The ability of each party both seller and buyer to influence the market.

e. Information and knowledge of sellers and buyers on the market at hand.

Of the various characteristics above the form or type of market is grouped into four types:

a. Perfect competition market, characterized by a large number of sellers and buyers.

b. Monopoly market, characterized by number, only one seller (mono).

c. Monopolistic competition market, characterized by a large number of sellers but each has the ability to influence the selling price.

d. Oligopoly market, characterized by a very small number of sellers between 2-10.

The perfect competition market is often referred to as pure competition (pure compotition). Pure competition is a market where there are many sellers so that the actions of each seller cannot influence the prevailing market price, either by changing the number of offers and the price of the product (Pracoyo \& Pracoyo, 2006, p. 190). Therefore, sellers in this market are price takers, because they can only sell their products at prices prevailing in the market.

\section{Perfect Competition.}

\section{a. In the market, there are many sellers and buyers.}


With so many sellers and buyers, no one party can influence the market. Because individuals, both sellers and buyers, are only a small percentage of the total buyers and sellers on the market. Everything on the market is a "price tracker" (price follower). This means that the price that occurs is more determined by the interaction between the seller and the buyer as a whole (Mankiw \& Taylor, 2006, p. 64).

\section{b. Goods that are traded must be the same or homogeneous.}

A product or item is called homogeneous if the product is identical. That is, between products with one another the exact same so that consumers will feel indifferent / the same in consuming these products. Products with one another are perfect subtitles / substitutes, thus the value / price of the product should be the same (Sawyer \& Sprinkle, 2015, p. 108).

\section{c. There is freedom to enter and exit the market (there is no barrier to entry or exit)}

In a perfectly competitive market, there is no single obstacle that can prevent a producer from entering or leaving the market. If a producer predicts that his business is no longer profitable, it can easily hinder the market. The obstacles that can prevent a producer from entering and leaving the market can be technical obstacles or legal obstacles (Fisher \& Waschik, 2005, p. 34).

\section{d. The existing production factors have perfect mobility.}

In perfectly competitive markets, all factors of production are assumed to have freedom of movement from one place to another. For example, in a rival market the wage rate is lower then he can easily withdraw the workforce to his company so that production costs for labor can be reduced (Agarwal, 2007, pp. 3-4).

\section{e. Both buyers and sellers have perfect information about the market.}

Each buyer and seller have perfect information about market conditions. Such information includes the price, quality, and quantity of an item. With complete information, market competition becomes truly perfect competition. For example, information about cheap raw materials, new production techniques are found so other companies will soon find out (Grant, 2013, p. 124).

In the case of Imperfect Competition Market, we try to look at the following illustration. In a market there is an oil company that has a considerable workforce. This affects the price of oil in the market. The illustration illustrates one form of imperfect competition market. So, imperfect competition markets will be formed if one of the conditions of perfect competition is not fulfilled.

\section{Monopolistic Competition}

Monopolistic Competition can be interpreted as a competitive monopoly market (Sitio, 2001, p. 100). From this understanding it can be concluded that, the market of a product is said to be in a state of monopolistic competition if in the market there are characteristics of competition and monopoly characteristics. This is because the products sold in the market are not homogeneous, but each has substitution with each other. 
Monopolistic competition is often found in service sectors and small trade. An example of this form of monopolistic competition is like a salon / hair trimmer, drug stores, grocery stores, where they are close to each other (Pracoyo \& Pracoyo, 2006, p. 229).

\section{Monopoly Market}

Monopoly based on the anti-monopoly law is control of the production or marketing of goods or for the use of certain services by one business actor or a group of business actors (Pracoyo \& Pracoyo, 2006, p. 217). The term monopoly comes from Greek monos polein which means "sell yourself". Therefore, experts argue that monopoly occurs when the output of the entire industry is produced and sold by just one company. As a sole seller, he has the power to set the price (price maker).

\section{Oligopoly Market}

In the oligopoly market there are few sellers or producers of goods or services. Because they are few in number, the actions of a seller to reduce the price of goods or services will affect the number of sales from other producers because buyers easily move from products to other products (Pride, Hughes, \& Kapoor, 2009, p. 22). Oligopoly theory has a long history, the term oligopoly was first used by Sir Thomas Moore in his 1916 work, "Utopia" 11. In the work it is said that prices do not have to be at the level of computation when the company is on more than one market. While the Oligopoly theory was first formalized by Augustin Cournot in 1838 through his work "Researches sur les Priciples methematiques de la theorie des richesses". Fifty years later, the theory was denied by Bertrand. Although a lot of criticism, but until now the Cournot theory is still considered a benchmark for other Oligopoly theories (Maisyarah, 2018).

\section{Indonesian Context}

With the current economic condition of Indonesia with the presence of large companies from foreign countries which simultaneously provide large-scale layoffs to their employees, it will greatly impact the current economic development and become a challenge especially for MSMEs (small and medium micro businesses) in Indonesia.

The Chairperson of the Dharma Bhakti Astra Foundation (Yayasan Dharma Bhakti Astra [YDBA]) FX Sri Martono added, globally the economy is still showing a signal that has not been too encouraging. One of them is because economic conditions in the European region have not improved, thus triggering a decline in market share for products produced by various countries such as Indonesia.

"This condition is certainly a challenge for MSMEs to be able to do business well. MSMEs need to have the courage to implement plans and make decisions that are supported by mastery of competencies and accurate data and information," concluded Sri Martono ('Makro | 2016, Kondisi Ekonomi Indonesia Diperkirakan Lebih Baik', n.d.).

\section{Overview of Islamic Economics}

Market in Islam is defined as a means of meeting between sellers and buyers, where a buyer comes to the market by renting a certain demand for goods to meet the seller who carries the same item offer. And the results of the meeting will result in an agreement between the 
seller and the buyer about the price level and the amount of goods in the transaction. If there is an agreement between the seller and the buyer, there is a provision for an item in the transaction (Zuhdi, 2002, p. 1100).

Market structure has an understanding, namely management of producers to several forms of markets based on their characteristics, such as the type of product produced, the number of companies in an industry. Whether or not it is easy to enter or enter into the industry and the role of advertising in industrial activities. The market for perfect competition in Islam confirms that the market must stand above the principle of free competition (perfect competition). But that does not mean that freedom is absolute. The freedom must be in accordance with sharia rules (Hassan \& Mahlknecht, 2011, p. 40). Perfect competition is a type of market with a very large number of sellers and buyers and products that are sold are homogeneous or similar and cannot be distinguished. A price is formed because of the market mechanism and the effect of the results of one supply and demand so that sellers and buyers in the market cannot influence the price and only act as price tracker (Jusmaliami, 2005, p. 200).

Perfect competition is the most ideal market structure because the market system is considered able to guarantee the existence of activities that produce high goods or services. However, in practice it is not easy to realize a market that has a perfect competitive structure (Curran, 2000, p. 206).

Whereas the imperfect competition market is the policy of a perfectly competitive market. Where between sellers and buyers, the amount is relative. Sometimes there is a market with a small number of sellers, and even one with only one seller. And it can also be the opposite, the number of buyers is even a small number of buyers. The monopoly market (Ihtik $\bar{d}$ ) is part of the imperfect competition market model. Monopoly market is a form of market where the market has only one seller who controls the market.(Karim, 2008, p. 173) A monopolist is a price maker; a monopolist can increase or decrease prices by determining the amount of goods to be produced. The more expensive the price of the item, and vice versa.

In Islam, the existence of one seller on the market or no competition, is not prohibited in Islam, however, he may not do an Ikhtikar. Because the idea is to take a profit above the normal profit by selling a small amount of goods to get a high price. So, markets like this are prohibited in Islam as said by the Prophet Muhammad pbuh.

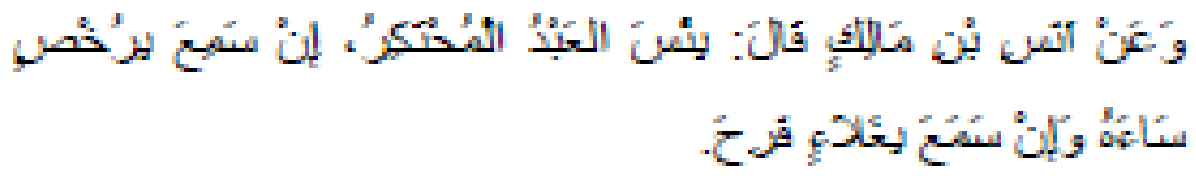

"From Anas ra, he said: at least the servant is a hoarder of goods. If he hears a cheap item, he is not happy and if the item becomes expensive, he is very happy."(Sabiq, 2009, p. 104).

Abu Hurairah narrated the Prophet's hadith about the prohibition of the Ihtikar as follows:

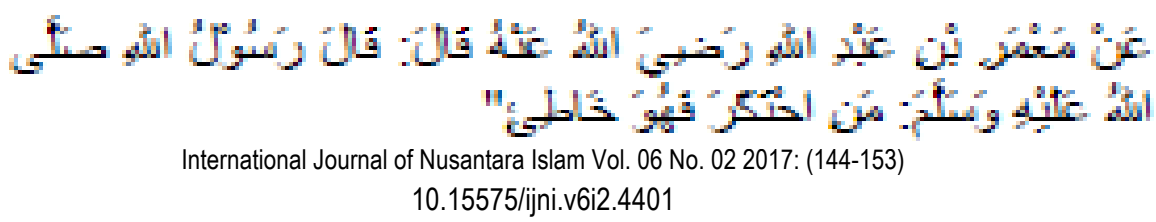


"From Ma'mar bin Abdillah ra, from the Messenger of All":: He said: "whoever conducts a consensus to damage the market price so that it rises sharply, then he sins." (Karim, 2008, p. 174).

The oligopoly market is a market where the supply of one type of goods is controlled by several companies. Generally, the number of companies is more than two but less than ten. In the oligopoly market, every company positions itself as a tying part of market play, where the profits they get depend on the behavior of their competitors. So that all promotional efforts, advertisements, introduction of new products, price changes, and so on are done with the aim of alienating consumers from their competitors (O'Connor, 2004, p. 118).

Oligopoly practices are usually carried out as an effort to detain companies from entering the market, companies do oligopoly as an effort to enjoy a profit by setting a limited selling price, thus causing price competition among business actors who practice oligopoly to become non-existent. The oligopoly market structure is generally formed in industries that have high capital, (Wensveen, 2012, p. 192) such as cement industry, automobile industry, and paper industry.

In the matter of price competition in Islam, price determination is one of the practices that is not allowed by Islamic Shari'a. The government or those who have economic power do not have the right and power to determine the fixed price of a commodity, unless the government has provided traders with a sufficient amount to sell using agreed prices.(Sadiq \& Cox, 2012, pp. 60-75). We can see this tabi'at (fixed-custom) from the attitude of the Prophet Muhammad pbuh on this issue. When visited by a companion to ask for a fixed price, he stated his rejection. He said:

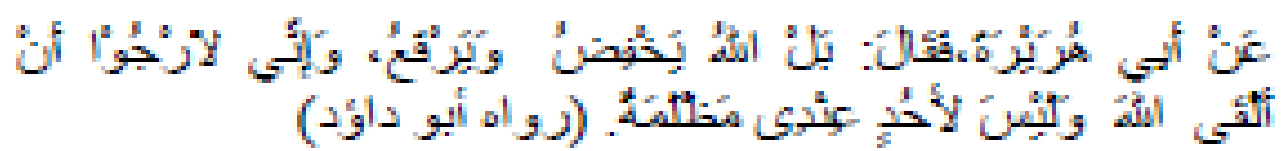

"From Abu Hurairah ra, he said: Price fluctuations (going up and down) are truly God's actions I want to meet Him and I do not do wrong to someone who can be sued from me "(Narrated by Abu Daud)(Daud, n.d., p. 3450).

The Islamic government, since the time of the Prophet has paid attention to the problem of price balance, especially in the role of the government in realizing price stability and overcoming the problem (Johan, 2015). However, some scholars reject the role of the government in interfering in economic affairs, one of which is the provision of pricing because based on a hadith of the Prophet pbuh as follows:

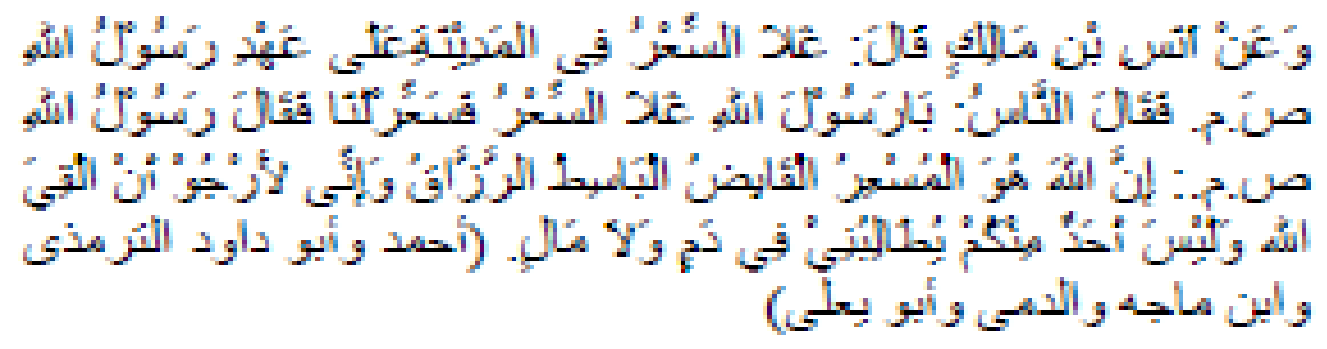


"Allah is the one who really determines the price, who revokes, expands and the risky giver. I hope that when meeting Allah there is no one among you who demands me about the existence of tyranny in matters of blood and property."(Sabiq, 2009, p. 101).

In the hadith, the Prophet asserted that interfering in the person of another person without any meaningful interest was an act of wrongdoing. However, if the market condition is not fair, such as the stockpiling of goods (ihtik d) by the merchant and the price play, then in such circumstances it can set a price with the aim of meeting the needs of the community and safeguarding from arbitrary and greedy acts. Thus, the purpose of the hadith above is not absolute about the prohibition of price fixing but setting prices has the purpose of eliminating danger and blocking one's wrongdoing (Tarmizi, 2017, p. 111). Even in Ibn Taimiyah's opinion distinguish two types of pricing: unfair and illegitimate, and fair and legitimate. "Unfair and illegitimate" pricing applies to rising prices due to free market competition, which results in a shortage of supply or an increase in demand (Setiawan, 2016).

For example, Ibn Taymiyyah stated "Forcing residents to sell merchandise without any basis of obligation to sell, is an unfair act and injustice is prohibited in Islam. But if the pricing is full of justice, for example, it prohibits them from adding to the price of oil, namely the price prevailing at that time in the market and forcing them to pay the price of oil. Then this is considered lawful and even obligatory, because if there is a seller who does not want to sell his goods, even though the goods are very much needed by the community, besides the community must add prices, this is where the halal is to force traders to sell their goods at the price of oil. And forcing pricing is a fair way to fulfill God's commands (Qardhawi, 2009, p. 355).

A real example of this market imperfection is due to the existence of a monopoly in trade in the form of food or goods. In such cases, the government must set a price to determine their sales and purchases. A monopolist must not be allowed to freely exercise his power.

In medieval times, Muslims strongly opposed the practice of accumulating goods and monopolies, and admiring monopolists was a sin. Despite opposing monopolistic practices, Ibn Taimiyah also allowed buyers to buy goods from monopolists, because if they were banned, the population would suffer even more. Therefore, Ibn Taymiyyah did not allow sellers to make an agreement to sell goods at a predetermined price level, between sellers and buyers, so that they formed the power to produce lower prices of merchandise, a case commonly called monopoly (Setiawan, 2016).

Ibn Taymiyyah also strongly opposed price discrimination against buyers or sellers who did not know the actual price that prevailed at the market at the time (mithli). He stated, "A seller is not allowed to set prices above the usual price, prices that are not common in society, from unconscious individuals (mustarsil) and must sell them at a general price level (alqimah al-mu'taddah). If a buyer has to pay an excessive price level, he has the right to improve the transaction. Someone knows, that discrimination in this way can be punished and excluded from entering the market. This opinion of Ibn Taymiyyah refers to the words of the Prophet Muhammad, "setting prices too high for people who do not realize they do not know is usury" (Qardhawi, 2009, p. 355).

\section{CONCLUSION}

International Journal of Nusantara Islam Vol. 06 No. 02 2017: (144-153)

10.15575/ijni.v6i2.4401 
From the results of a literature review that has been done, the conclusions that can be drawn from this study are:

1. The condition of the market structure in Indonesia must be improved by the existence of perfect or imperfect competition markets, although in reality it is quite difficult to implement a perfectly competitive market. In imperfect competition markets in terms of market monopoly must be able to regulate the issue of pricing well and not take profits above profits. Especially for the Indonesian people who have not been involved in the business world it would be good to be able to participate in becoming a micro business in Indonesia because with the many micro entrepreneurs for beginners in the field of entrepreneurship will help improve the economy in Indonesia.

2. In terms of price competition, for business actors in the form of micro and macro businesses in pricing, it is not good to follow in accordance with the demand and supply that occurs in the market, in the form of price determination is one of the practices that is not permitted by Islamic law. The government or those who have economic power do not have the right and power to determine the fixed price of a commodity, unless the government has provided traders with a sufficient amount to sell using agreed prices. We can see this tabi'at (fixed) from the attitude of the Prophet Muhammad on this issue. When the Prophet pbuh was visited by a companion to ask for a fixed price, he stated his rejection.

\section{REFERENCES}

Agarwal, S. K. (2007). Business Economics (For CA Foundation), 5e. New Dehli: S. Chand Publishing.

Arnold, R. A. (2008). Microeconomics. Mason: Cengage Learning.

Baumol, W., \& Blinder, A. (2008). Microeconomics: Principles and Policy. Mason: Cengage Learning.

Beckert, J. (2009). Beyond the Market: The Social Foundations of Economic Efficiency. Princeton-Oxford: Princeton University Press.

Curran, J. (2000). Taking the Fear Out of Economics. London: Cengage Learning EMEA.

Daud, A. (n.d.). Shahih Sunan Abu Daud (3rd ed.).

Fisher, T., \& Waschik, R. (2005). Managerial Economics: A Game Theoretic Approach. London-New York: Routledge.

Grant, S. (2013). Cambridge International AS and A Level Economics Revision Guide. Delhi: Cambridge University Press.

Hassan, K., \& Mahlknecht, M. (2011). Islamic Capital Markets: Products and Strategies. New Dehli: John Wiley \& Sons. 
Johan, A. (2015). MONOPOLY PROHIBITION ACCORDING TO ISLAMIC LAW: A LAW AND ECONOMICS APPROACH. Mimbar Hukum - Fakultas Hukum Universitas Gadjah Mada, 27(1), 166-178. https://doi.org/10.22146/jmh.15904 Jusmaliami. (2005). "Kebijakan Ekonomi dalam Islam. Yogyakarta: Kreasi Wacana. Karim, A. (2008). Bank Islam: analisis fiqih dan keuangan. Jakarta: RajaGrafindo Persada. Klein, K. C. (2010). Supply, Demand, and Equilibrium. In R. C. Free (Ed.), 21st Century Economics: A Reference Handbook. New Dehli: SAGE.

Maisyarah, R. (2018). Analysis of the Determinants Competition Oligopoly Market Telecommunication Industry in Indonesia. KnE Social Sciences, 3(10), 760-770. https://doi.org/10.18502/kss.v3i10.3170

Makro | 2016, Kondisi Ekonomi Indonesia Diperkirakan Lebih Baik. (n.d.). Retrieved from http://ekonomi.metrotvnews.com/read/2016/02/25/490074/2016-kondisi-ekonomiindonesia-diperkirakan-lebih-baik

Mankiw, N. G., \& Taylor, M. P. (2006). Economics. London: Cengage Learning EMEA.

O'Connor, D. E. (2004). The Basics of Economics. Westport-Connecticut-London: Greenwood Publishing Group.

Pate, S. (2012). CliffsNotes Praxis II: Social Studies Content Knowledge (0081), 2nd Edition. Hoboken: Houghton Mifflin Harcourt.

Pracoyo, T. K., \& Pracoyo, A. (2006). Antyo Pracoyo, "Aspek Dasar Ekonomi Mikro". Jakarta: PT. Gramedia Widiasarana Indonesia.

Pride, W., Hughes, R., \& Kapoor, J. (2009). Business. Mason: Cengage Learning.

Qardhawi, Y. (2009). Halal dan Haram dalam Islam. Bina IImu.

Sabiq, S. (2009). "Fiqih Sunnah Juz 12". Cakrawala Surya Prima.

Sadiq, S., \& Cox, S. (2012). Murabaha Based Trade Financing. In H. A. Dar \& U. F. Moghul (Eds.), The Chancellor Guide to the Legal and Shari'a Aspects of Islamic Finance. Harriman House Limited.

Sawyer, W. C., \& Sprinkle, R. L. (2015). Applied International Economics. London-New York: Routledge.

Setiawan, R. A. (2016). THE RELEVANCE OF IBN TAYMIYYAH ECONOMICS IN ADDRESSING POVERTY AND INCOME DISTRIBUTION. MADANIA: JURNAL KAJIAN KEISLAMAN, 20(1), 13-22. https://doi.org/10.29300/madania.v20i1.82 
Sitio, A. (2001). Halomoan Tamba, "KOPERASI, Teori dan Praktik". Jakarta: Erlangga.

Tarakan, P. K. M. (2000). Predatory Pricing and Anti Dumping. In G. Norman \& J.-F. Thisse (Eds.), Market Structure and Competition Policy: Game-Theoretic Approaches. Cambridge: Cambridge University Press.

Tarmizi, E. (2017). Haram Wealth in Contemporary Muamalah. Bogor: Berkah Mulia Insani.

Thomas, R. M. (1998). Conducting Educational Research: A Comparative View. WestportConnecticut-London: Greenwood Publishing Group.

Tucker, I. (2008). Microeconomics for Today. Mason: Cengage Learning.

Wensveen, D. J. G. (2012). Air Transportation: A Management Perspective. SurreyBurlington: Ashgate Publishing, Ltd.

Zuhdi, S. (2002). Sejarah Perkembangan Pelabuhan di Indonesia. In B. B. Utomo, S. Zuhdi, \& Widiati, Jejak-jejak Tinggalan Budaya Maritim Nusantara (pp. 8-17). Jakarta: Direktorat Jenderal Kebudayaan. 